\title{
Effects Of Environmental Uncertainty On Perception Of Information Systems Issues
}

Arthur H. Gilbert, Jr., (E-mail: gilberta@umkc.edu), University of Missouri, Kansas City Roger Alan Pick, (E-mail: pick@acm.org), University of Missouri, Kansas City

Sidne Gail Ward, (E-mail: wards@umkc.edu), University of Missouri, Kansas City

\begin{abstract}
The current study reports the results of a survey of CEOs and senior information systems managers to examine the relationship between perceived environmental uncertainty (PEU) and IS issues that have appeared repeatedly in MIS Quarterly. Senior Information Systems managers in high$P E U$ firms ranked a number of issues differently than those in low-PEU firms. Additionally, information systems issues overall are more important on average in high-PEU firms than in lowPEU firms. Also, high PEU results in some issues concerning external information to be deemed more important. A comparison of factor analyses for the two groups indicates firms reporting high levels of PEU view external IS issues differently than those firms with low levels of PEU; external IS issues load on a separate construct for high-PEU firms. That construct is not found in low-PEU firms.
\end{abstract}

\subsection{Introduction}

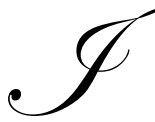

nformation systems (IS) scholars have repeatedly found the study of IS issues a fertile ground for research that has even, on occasion, guided IS practitioners and consultants in the allocation of scarce resources among competing priorities. Palvia and Basu (1999) cast some doubt on the relevance of IS issues research. The current study addresses some of the questions raised by Palvia and Basu and examines the relationship between continuing IS issues and perceived environmental uncertainty (PEU).

\subsection{Review of the Literature}

\subsection{Information Systems Issues Research}

The study of IS issues has developed into a significant body of research incorporating a number of perspectives. Some studies are general and address IS issues from the perspective of IS managers in multi-industry settings in the United States. Examples of this research include Ball and Harris (1982); Clark (1992), Neiderman, Brancheau, and Wetherbe (1991); Brancheau, Janz, and Wetherbe (1996); and Gilbert, Pick, and Ward (1999). Other studies have a different scope. Watson (1989) and Wang (1994) address IS issues in Australia and China, respectively. Caudle, Gorr, and Newcomer (1991) investigate MIS issues in the public sector. Couger (1988) compares the positions on IS issues of IS executives with those of human resources executives. Gilbert, Pick, and Ward (2000) address IS issues in manufacturing firms. Gottschalk (2000) composes an overview of this literature. Palvia et al (2002) conduct a meta-analysis that looks for patterns in studies conducted in various countries and finds a pattern of difference according to the country's level of development.

While issues research is well-established in the mainstream IS literature, it is not without criticism. Palvia and Basu (1999) question the relevance of the IS issues research to that date in that it was retrospective and, therefore, addressed issues which may or may not be relevant in the future.

Readers with comments or questions are encouraged to contact the authors via email. 


\subsection{Information Systems and Perceived Environmental Uncertainty}

Organizations must deal with an environment including such actors as suppliers, customers, competitors and the government. In manufacturing firms, uncertainty in the environment can be compensated for by such things as inventory, lead time or excess capacity (Pagell et al. 2000). Information systems can also serve as a mechanism to deal with environmental uncertainty. Following Sathe and Watson (1987), we are interested in those factors external to the organization that affect organization structure and information flows. We believe that uncertainty in the environment, or rather the perception that such uncertainty exists, affects information needs and therefore the information systems function. Since Duncan (1972) first coined the term researchers have sought to understand the impact of perceived environmental uncertainty (PEU) on the organization. PEU is defined as top management's perception of its own inability to predict the organization's external environment with acceptable accuracy (Milliken 1987). Also since the definition of the concept, researchers have examined PEU as a possible influence on information systems. Gordon and Miller (1976) examine the relationships among a number of IS variables, including such environmental variables as dynamism, hostility, and heterogeneity. Each of these is an element of PEU. Gordon and Miller (1976) suggest that as environmental dynamism increases, the effective information system incorporates more non-financial and qualitative information, makes greater use of forecast information, and increases the frequency of reporting. As environmental hostility increases, their paper proposes that the effective information system provides continuous reporting and substantial data to aid in identifying strengths, opportunities, and weaknesses. As environmental heterogeneity increases, Gordon and Miller (1976) suggest that the effective information system provides information so that management can rapidly measure the performance of individual strategic business units.

The descriptions of prospectors and defenders in Miles and Snow's (1978) typology support the idea that those in a high-PEU organization have a greater need for information about the organization's environment. Prospectors scan the environment for new opportunities and build systems to support these activities. Defenders do not believe factors in the environment significantly affect their operations. Prospectors have been equated with highPEU firms (Simons 1987; Govindarajan 1984) while low-PEU firms are often defenders (Miller 1983).

Additional research work examines the relationship between information systems and PEU as well as similar measures of uncertainty. Gordon and Narayanan (1984) find that management's perception of uncertainty in the environment drives decisions concerning information requirements. Chenhall and Morris (1986) detect a significant relationship between PEU, the perceived usefulness of broad scope information, and timeliness of information. Gul (1991) shows that task uncertainty affects the impact of accounting systems on performance. Gul and Chia (1994) demonstrate that interactions between PEU and management accounting systems design affect managerial performance. Raymond, Paré, and Bergeron (1995) determine that firms with a high PEU level exhibit more sophisticated uses of information technology and perform more poorly than firms operating under low PEU conditions. Fisher (1996) examines the effects of PEU on individual differences and discovers that managers who believe events are largely outside their personal locus of control find information more useful when faced with high PEU. Chong (1997) finds PEU to be an important antecedent of systems design. Similarly, Gilbert and Singer (1999) determine that PEU has a significant impact on IS design as well as on the firm's business strategy. Choe, Lee, and Park (1998) demonstrate the existence of a direct positive relationship between PEU and facilitators of IS alignment such as IS management involvement in the strategic planning process for the organization. Their paper finds only an indirect relationship between PEU and strategic IS applications.

While the impact of PEU on a number of IS-related variables has been the subject of inquiry, only Ward et al (2003) study the relationship between PEU and the importance attached to various IS issues. They determine that IS managers in firms operating with high levels of PEU generally consider IS issues to be of greater concern than do IS managers in firms faced with low levels of PEU. The literature as cited above indicates that the level of PEU affects the design of IS, the information requirements of the firms, additional aspects of IS, and Chief Information Officers' (CIOs') views about the relative importance of IS issues facing their organizations. We hypothesize that CIOs of firms in highly uncertain environments view the importance of IS issues differently than CIOs in less uncertain environments. In particular, CIOs of firms experiencing high levels of PEU will attach a different level of importance to IS issues that are related to the external environment. Although Ward et al (2003) study PEU and IS issues, they use a different research model than the present paper, and they do not examine the underlying factor structure. 
Differences in the views of IS issues between CIOs operating under dissimilar levels of uncertainty result since people value certainty. By definition, information reduces uncertainty about the state of nature. Thus, if people believe they are in an uncertain environment (e.g., if they perceive environmental uncertainty), they will seek information in order to reduce the uncertainty. This desire for information will have an impact upon how they think about the systemsq which systematically generate information. This idea is expressed both in Figure One and in the following two hypotheses:

Figure 1 Impact of PEU on IS Issues

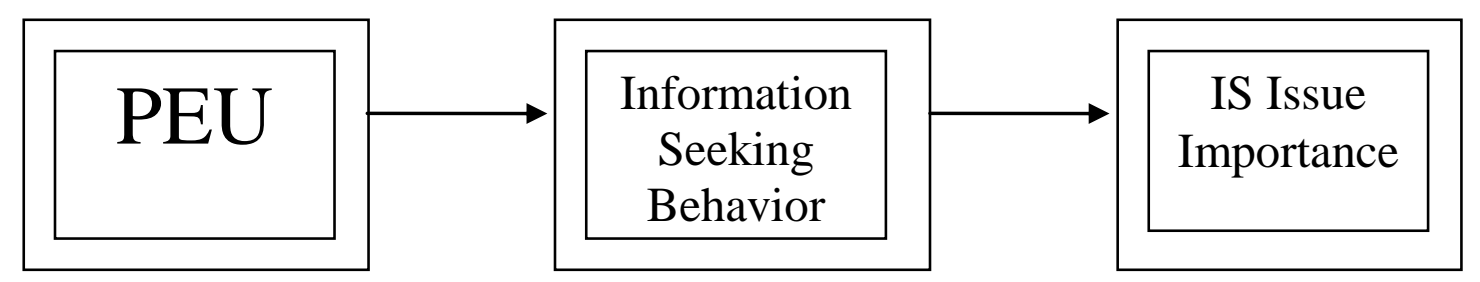

H1: CIOs in high PEU firms attach a different level of importance to IS issues in general than CIOs in low PEU firms.

Furthermore, since PEU deals with the conditions outside of the firm, we hypothesize that IS issues related to factors external to the organization are more important to CIOs in firms with a high level of PEU than to CIOs in firms experiencing lower levels of PEU.

H2: CIOs in high PEU firms attach a higher level of importance to external IS issues than CIOs in low PEU firms.

This study examines the relationship between the importance of IS issues and PEU.

\subsection{Methods}

\subsection{Selection of Issues and Questionnaire Design}

Five articles from MIS Quarterly (Ball and Harris 1982; Dickson et al. 1984; Brancheau and Wetherbe 1987; Neiderman et al. 1991; and Brancheau et al. 1996) over the last two decades provide the population of IS issues that we considered studying. Palvia and Basu (1999) are concerned with the relevance of current IS issues research due to the ephemeral nature of some of the issues and we share this misgiving. Obviously, some issues are fleeting concerns as the profession learns to deal with them, these concerns diminish in importance. Examples of issues that once appeared in surveys of CIOs and later disappeared are decision support tools and CASE tools. Perhaps the Internet is an important issue today, but it very well might become unimportant as an issue as its capabilities and business implications are better understood. In contrast, other issues remain relevant over time and continue to present long-term concerns for IS professionals. Issues that have remained important over two decades include using IS for competitive advantage, promoting the effective use of the data resource, and aligning the IS organization with that of the enterprise. Gilbert, Pick, and Ward (1999) address the transitory nature of IS issues.

We are studying issues that have shown staying power. These are defined as those which appear in a majority (at least three) of the MIS Quarterly articles listed above. This operationalizes a notion of continuing relevance over time. By including only issues that have surfaced repeatedly over a number of years, we address Palvia and Basu's (1999) claim that IS issues studies have no current relevance. Although this claim may apply to some issues, we argue that at least some IS issues that have a record of persistence will continue to be relevant. As the wording for a given issue may vary from one study to the next, the various articles were carefully examined to iden- 
tify when IS issues appeared to be the same despite slight differences in phrasing. The issues were evaluated independently by each author with a consensus required for inclusion of the issue in the analysis. The questionnaire presents the IS issues with the exact phrasing used by the middle study (Brancheau and Wetherbe 1987). Following this procedure, fifteen continuing issues were identified. These issues are shown in Table 1. The survey instrument asked respondents to rate the importance of each issue using a seven-point Likert scale with anchor values of $1=$ "Not Important" to 7 = "Extremely Important."

\section{Table 1 List of Issues}

\section{Short Title}

Full Text of Survey Item

Competitive Advantage

EDI

Strategic Planning

End User

Software Development

Effectiveness \& Productivity

Organizational Learning

Alignment

Human Resources

Data Resources

Applications Portfolio

Telecommunications

Role of IS

Security \& Control

Information Architecture
Using information systems for competitive advantage.

Enabling electronic data interchange and multi-vendor integration.

Improving information systems strategic planning.

Facilitating and using end-user computing.

Improving the effectiveness of software development.

Measuring information systems effectiveness and productivity.

Facilitating organizational learning and the use of information systems.

Aligning the information systems organization with that of the enterprise.

Specifying, recruiting, and developing information systems human resources.

Promoting effective use of the data resource.

Planning and managing the applications portfolio.

Planning, implementing, and managing telecommunications.

Increased understanding of the roles and contributions of information systems. Improving information security and control.

Developing an information architecture.

Perceived environmental uncertainty (PEU) was measured through Miller and Droge's (1986) psychometric scale. This scale measures the degree of change and unpredictability in market-related and technological factors facing the organization. Individual items comprising the scale are shown in Table 2.

\section{Table 2 Variable Scale Items Perceived Environmental Uncertainty}

Consider the conditions in the industry in which your firm operates. For each item, please answer by circling the number that best approximates the actual conditions in your industry.

1. Our firm must rarely change its marketing practices

to keep up with the market and competitors

2. The rate at which products/services are becoming obsolete is very low

(e.g., basic metals such as copper

3. Actions of competitors are quite easy to predict

4. Demand and consumer tastes are fairly predictable (e.g., for milk companies)

5. The production/service technology is not subject to very much change and is well established

(e.g., steel production)
1234567 Our firm must change its marketing practices extremely frequently (e.g. semi-annually)

1234567 The rate of obsolescence if very high, as in some fashion goods

1234567 Actions of competitors are unpredictable

1234567 Demand and tastes are almost unpredictable (e.g., high fashion goods)

1234567 The modes of production/service change often and in a major way (e.g., advanced electronic components) 


\subsection{Sampling Frame}

The survey instrument was sent to all firms in the Compact Disclosure database which operate in a single industry as identified by four-digit Standard Industrial Classification (SIC) code. The sample was limited to firms operating in single industries because competition in multiple industries might confound our results. The level of uncertainty reflected in different industries might be markedly different. In addition, firms having operations in multiple industries might have different IS issues facing them in each line of business. The selection criterion resulted in 1,948 firms being chosen for this study.

Two survey instruments were mailed to the chief executive officer (CEO) of each firm. A cover letter accompanying the instruments requested that the CEO answer the questions concerning PEU and forward the questionnaire addressing the IS issues to the person considered "most knowledgeable about the organization's information system." Inasmuch as the titles of IS managers vary among firms, the authors felt this would be the most effective way to route the survey instrument to the senior IS manager, regardless of that person's formal title. We operationalize the term Chief Information Officer (CIO) to refer to this most knowledgeable person.

\subsection{Respondents}

We needed to receive a questionnaire back from both the CEO and the CIO in order to conduct the analysis for this study. Survey instruments were received from 210 CEOs (10.8 percent response rate) and 228 IS managers (11.7 percent response rate). Both the CEO and CIO from 106 firms returned questionnaires for an effective response rate of 5.4 percent. Of these, 102 survey instruments were complete and are included in this study. The anonymity of the respondents and their firms could not be guaranteed because the responses from the two respondents from each firm had to be paired. Considering that two very high-level individuals in each organization were required to complete the questionnaires and anonymity could not be assured, this response rate was deemed acceptable. This level of response is not uncommon in published industrial research. For instance, Dwyer and Welsh (1985) report a response rate of 6.3 percent in their survey of industrial firms. The responses represent a broad cross-section of the economy. To get a sense of industrial coverage, Table 3 shows the distribution of responding firms by two-digit (rather than four-digit for brevity) SIC code for which responses were received from both the CEO and the CIO. Completed questionnaires were divided into quartiles based upon receipt date. We compared the earliest quartile against the last quartile using a multivariate test and found no evidence of a response bias.

\subsection{Results}

The PEU construct reflects a mean value of 3.8248 and Cronbach Alpha of .8371. Firms with PEU above the mean are classified as high-PEU firms $(\mathrm{N}=56)$. Firms with PEU at or below the mean are classified as low-PEU firms $(\mathrm{N}=46)$.

The five most important issues, from most important to less important, for high-PEU firms are Alignment, Competitive Advantage, Information Architecture, Strategic Planning, and Data Resources/End User (tie), respectively. For low-PEU firms, the five most important issues in declining order of importance, are End User, Data Resources, Alignment, Competitive Advantage, and Organizational Learning. The most prominent result is that Competitive Advantage, an issue with great external focus, is second in importance for high-PEU firms and fourth in importance for low-PEU firms. The other purely-external issue, EDI, received similar low rankings from CIOs of both high and low PEU firms. Also striking is that more internally-directed issues, End User and Data Resource, are first and second, respectively, for low-PEU firms but only tied for fourth in high-PEU firms. Complete results are presented in Table 4. The average level of importance per issue reported for low-PEU firms is 4.88 while high-PEU firms report an average level of importance of 5.29 per issue. 
Table 3 Distribution of Respondents by Two-digit SIC Code

\begin{tabular}{|c|c|c|}
\hline$\underline{\text { SIC Code }}$ & Description & Res] \\
\hline 07 & Agricultural Services & 1 \\
\hline 10 & Metal Mining & 1 \\
\hline 13 & Oil \& Gas Extraction & 6 \\
\hline 22 & Textile Mill Products & 1 \\
\hline 26 & Paper \& Allied Products & 1 \\
\hline 27 & Printing \& Publishing & 2 \\
\hline 28 & Chemicals \& Allied Products & 5 \\
\hline 30 & Rubber \& Misc Plastic Products & 1 \\
\hline 31 & Leather \& Leather Products & 1 \\
\hline 32 & Stone, Clay, \& Glass Products & 1 \\
\hline 33 & Primary Metal Industries & 3 \\
\hline 35 & Industrial Machinery \& Equipment & 6 \\
\hline 36 & Electronic \& Other Electric Equipment & 4 \\
\hline 38 & Instruments \& Related Equipment & 8 \\
\hline 39 & Misc Manufacturing Industries & 1 \\
\hline 45 & Transportation by Air & 1 \\
\hline 47 & Transportation Services & 1 \\
\hline 48 & Communications & 3 \\
\hline 49 & Electric, Gas, \& Sanitary Services & 13 \\
\hline 50 & Wholesale Trade-Durable Goods & 1 \\
\hline 52 & Building Materials \& Garden Supplies & 1 \\
\hline 53 & General Merchandise Stores & 1 \\
\hline 56 & Apparel \& Accessory Stores & 1 \\
\hline 57 & Furnishings \& Home Furnishing Stores & 1 \\
\hline 58 & Eating \& Drinking Establishments & 3 \\
\hline 59 & Miscellaneous Retail & 4 \\
\hline 60 & Depository Institutions & 5 \\
\hline 61 & Nondepository Institutions & 4 \\
\hline 62 & Security \& Commodity Brokers & 1 \\
\hline 63 & Insurance Carriers & 4 \\
\hline 65 & Real Estate & 1 \\
\hline 70 & Hotel \& Other Lodging Places & 1 \\
\hline 72 & Personal Services & 1 \\
\hline 73 & Business Services & 3 \\
\hline 79 & Amusement \& Recreation Services & 2 \\
\hline 80 & Health Services & 4 \\
\hline 83 & Social Services & 1 \\
\hline \multirow[t]{2}{*}{87} & Engineering \& Management Services & $\underline{7}$ \\
\hline & Total & 106 \\
\hline
\end{tabular}

A multivariate analysis of variance shows that there is a statistically significant difference in the level of importance attached to IS issues in general by CIOs of firms operating in more uncertain environments relative to those CIOs whose firms are in low uncertainty environments. Specifically, three different multivariate tests (Pillais, Hotelling, and Wilks) all found P-value of .06. A significant difference at the $90 \%$ level is thus demonstrated in the level of importance attached to IS issues in general by high-PEU firms versus low-PEU firms. Hypothesis 1 is weakly supported. 
Table 4 Comparison of the Importance Ranking of Issues Low-PEU Versus High-PEU Firms

\begin{tabular}{|c|c|c|c|c|}
\hline \multirow[b]{2}{*}{ Issue } & \multicolumn{2}{|c|}{$\underline{\text { Low PEU Firms }}$} & \multicolumn{2}{|c|}{ High PEU Firms } \\
\hline & Rank & Mean & Rank & Mean \\
\hline End User & 1 & 5.50 & $6 *$ & 5.46 \\
\hline Data Resources & 2 & 5.32 & $5^{*}$ & 5.46 \\
\hline Alignment & 3 & 5.30 & 1 & 6.04 \\
\hline Competitive Advantage & 4 & 5.23 & 2 & 5.78 \\
\hline Organizational Learning & 5 & 5.09 & 7 & 5.30 \\
\hline Strategic Planning & 6 & 5.02 & 4 & 5.50 \\
\hline Information Architecture & 7 & 4.93 & 3 & 5.59 \\
\hline Role of IS & 8 & 4.91 & $11 *$ & 5.11 \\
\hline Effectiveness \& Productivity & 9 & 4.87 & $10 *$ & 5.11 \\
\hline Telecommunications & 10 & 4.81 & 8 & 5.21 \\
\hline Software Development & $11^{*}$ & 4.74 & 9 & 5.16 \\
\hline Applications Portfolio & $12 *$ & 4.74 & $13 *$ & 4.96 \\
\hline Security \& Control & 13 & 4.57 & $14^{*}$ & 4.96 \\
\hline EDI & 14 & 4.37 & 15 & 4.75 \\
\hline Human Resources & 15 & 3.74 & 12 & 4.98 \\
\hline
\end{tabular}

Univariate analyses of variance were then performed on the IS issues. These results are found in Table 5. CIOs of high PEU firms rated Competitive Advantage, Strategic Planning, Alignment, Human Resources, and Information Architecture as significantly more important (10\% or higher level) than did CIOs of low-PEU firms. The CIOs of firms experiencing high levels of uncertainty in the environment rated EDI, Software Development, Effectiveness \& Productivity, Organizational Learning, Data Resources, Applications Portfolio, Telecommunications, Role of IS, and Security \& Control as more important than the CIOs of firms in more certain environments, but the difference was not significant. End User was the only issue which was rated more important in a low-PEU setting, and the difference was not significant. Many of the issues are more important in a high-PEU setting than in a lowPEU setting, but we did not see a definite pattern of importance attached to externally-focused issues exclusively. Thus, we see support for a reworded hypothesis.

\section{H': CIOs in high PEU firms attach a higher level of importance to IS issues than CIOs in low PEU firms.}

We agree with Palvia and Basu (1999) that specific IS issues may not represent unique constructs. In order to more easily compare the differences in the importance CIOs of low-PEU companies place on the various IS issues versus that placed by CIOs of high-PEU companies, we conducted an exploratory factor analysis in search of more fundamental or higher level constructs. The separate analyses for each group reduced the number of issues and allowed us to examine the underlying structure of those issues. The underlying factors for each group were then compared.

A varimax rotation was employed which resulted in interpretable factors. Employing the criterion of eigenvalues greater than or equal to one determined the number of factors to retain in each analysis.

For the low-PEU group, all of the variables loaded on three factors. The eigenvalue for the third factor was 1.04, indicating that all three factors should be retained. The three factors are shown in Table 6 . The items which load most heavily on the first factor include Data Resources, Security \& Control, Competitive Advantage, Role of IS, and End User. All of these issues involve advocacy of the IS function both within the overall organization (e.g., end user computing) and with an outward focus (e.g., competitive advantage). We have termed this factor Advocacy.

Items loading on the second factor for the low-PEU organizations include EDI, Telecommunications, Alignment, Human Resources, Strategic Planning, Effectiveness \& Productivity, and Information Architecture. This factor is termed Strategy. 
Table 5 Univariate Analyses of Variance Low Versus High Levels of PEU

\begin{tabular}{|c|c|c|c|c|}
\hline Issue & $\begin{array}{l}\text { PEU } \\
\text { Level }\end{array}$ & Mean & $\begin{array}{l}\text { Standard } \\
\text { Deviation }\end{array}$ & $\begin{array}{l}\text { Univariate F } \\
\text { (P-Value) }\end{array}$ \\
\hline \multirow[t]{2}{*}{ Competitive Advantage } & Low & 5.23 & 1.99 & 2.89 \\
\hline & High & 5.78 & 1.46 & $(.09)$ \\
\hline \multirow[t]{2}{*}{ EDI } & Low & 4.37 & 2.08 & .89 \\
\hline & High & 4.75 & 1.72 & $(.35)$ \\
\hline \multirow[t]{2}{*}{ Strategic Planning } & Low & 5.02 & 1.78 & 3.45 \\
\hline & High & 5.50 & 1.19 & $(.07)$ \\
\hline \multirow[t]{2}{*}{ End User } & Low & 5.50 & 1.46 & .00 \\
\hline & High & 5.46 & 1.01 & $(.97)$ \\
\hline \multirow[t]{2}{*}{ Software Development } & Low & 4.74 & 1.96 & 1.49 \\
\hline & High & 5.16 & 1.52 & $(.23)$ \\
\hline Effectiveness \& & Low & 4.87 & 1.69 & .98 \\
\hline Productivity & High & 5.11 & 1.12 & $(.33)$ \\
\hline \multirow[t]{2}{*}{ Organizational Learning } & Low & 5.09 & 1.35 & 1.62 \\
\hline & High & 5.30 & 1.26 & $(.21)$ \\
\hline \multirow[t]{2}{*}{ Alignment } & Low & 5.30 & 1.60 & 9.21 \\
\hline & High & 6.04 & 1.01 & $(.00)$ \\
\hline \multirow[t]{2}{*}{ Human Resources } & Low & 3.74 & 1.89 & 13.71 \\
\hline & High & 4.98 & 1.59 & $(.00)$ \\
\hline \multirow[t]{2}{*}{ Data Resources } & Low & 5.32 & 1.42 & .63 \\
\hline & High & 5.46 & .99 & $(.43)$ \\
\hline \multirow[t]{2}{*}{ Applications Portfolio } & Low & 4.74 & 1.69 & .79 \\
\hline & High & 4.96 & 1.29 & $(.38)$ \\
\hline \multirow[t]{2}{*}{ Telecommunications } & Low & 4.81 & 1.84 & 1.83 \\
\hline & High & 5.21 & 1.56 & $(.18)$ \\
\hline \multirow[t]{2}{*}{ Role of IS } & Low & 4.91 & 1.64 & .92 \\
\hline & High & 5.11 & 1.29 & $(.34)$ \\
\hline \multirow[t]{2}{*}{ Security \& Control } & Low & 4.57 & 1.65 & 2.44 \\
\hline & High & 4.96 & 1.29 & $(.12)$ \\
\hline \multirow[t]{2}{*}{ Information Architecture } & Low & 4.93 & 1.63 & 5.70 \\
\hline & High & 5.59 & 1.08 & $(.02)$ \\
\hline
\end{tabular}

Items loading on the third factor for the low-PEU organizations include the Applications Portfolio, Organizational Learning, and Software Development. This factor is termed Technology.

For the high-PEU group, the variables loaded on four factors, the fourth of which had an eigenvalue of 1.02 , meeting the criterion for retention. The four factors are shown in Table 7. 
Table 6 Low PEU Varimax Rotated Factor Matrix

\begin{tabular}{|c|c|c|c|c|}
\hline & & Advocacy & Strategy & Technology \\
\hline Eigenvalue & 8.307 & 1.293 & & 1.044 \\
\hline Data Resources & & .786 & .072 & .479 \\
\hline Security \& Control & & .748 & .246 & .087 \\
\hline Competitive Advantage & & .745 & .445 & -.007 \\
\hline Role of IS & & .741 & .327 & .286 \\
\hline End User & & .610 & .259 & .363 \\
\hline EDI & & -.027 & .763 & .304 \\
\hline Telecommunications & & .496 & .695 & .089 \\
\hline Alignment & & .438 & .682 & .185 \\
\hline Human Resources & & .316 & .667 & .304 \\
\hline Strategic Planning & & .460 & .665 & .308 \\
\hline Effectiveness \& Productivity & & .378 & .599 & .407 \\
\hline Information Architecture & & .468 & .593 & .281 \\
\hline Applications Portfolio & & .006 & .313 & .873 \\
\hline Organizational Learning & & .408 & .197 & .756 \\
\hline Software Development & & .308 & .354 & .662 \\
\hline
\end{tabular}

Items loading on the first factor for the high-PEU organizations include Strategic Planning, Alignment, Information Architecture, Organizational Learning, Human Resources, and Effectiveness \& Productivity. This factor is termed Internal Strategy. Items loading on the second factor for the organizations reporting a high level of PEU include Data Resources, End User, Role of IS, and Security \& Control. This factor is termed Internal Advocacy. Items loading on the third factor for the high-PEU organizations include Software Development, Applications Portfolio, and Telecommunications. This factor is termed Internal Technology. The fourth factor for the high-PEU organizations is comprised of two items, EDI and Competitive Advantage. This factor is termed External.

\subsection{Discussion}

We argue that managers who believe they are operating in an uncertain environment will have a greater need for information to determine the state of that environment than managers who believe their firms operate in relatively certain environments. Thus, information systems issues will have more importance for those in a highPEU firm. The need for information to reduce uncertainty affects how managers think about the systems capturing that information and presenting it. The dissimilar environments in which the two groups of firms operate are reflected in both the importance attached to various IS issues and the underlying factor structure of those issues.

We would not have expected a significant difference in the importance attached to issues that have an internal focus between the two groups. We expect that, regardless of the environment, the internal state of the firm would be equally well-understood by firms in each group. High-PEU firms would distinguish between internal and external information issues because there is a much greater need and urgency for information about the environment. In contrast, the low-PEU firm should see less of a contrast between internally-generated and externally-generated information because neither is associated with a high degree of perceived uncertainty.

We find that that the IS issues addressed in this study are considered differently, in terms of importance, in low-PEU firms relative to high-PEU firms. High-PEU organizations attach a higher level of importance to many of these continuing IS issues than do low-PEU organizations. Many of the issues are more important at high-PEU firms than at low-PEU firms. This appears to support the contention that high-PEU firms place greater importance on information systems in dealing with key issues and maintaining their competitive position than do low-PEU firms. In addition, the ranking of issues in terms of relative importance is different in the two groups. 
Table 7 High PEU Varimax Rotated Factor Matrix

\begin{tabular}{lllll}
\hline \hline & $\begin{array}{l}\text { Internal } \\
\text { Strategy }\end{array}$ & $\begin{array}{l}\text { Internal } \\
\text { Advocacy }\end{array}$ & $\begin{array}{l}\text { Internal } \\
\text { Technology }\end{array}$ & External \\
\hline Eigenvalue & 6.86 & 1.25 & 1.18 & 1.02 \\
Strategic Planning & .781 & .113 & .060 & .386 \\
Alignment & .718 & .227 & .294 & .030 \\
Information Architecture & .700 & .177 & .336 & .147 \\
Organizational Learning & .680 & .460 & -.091 & .077 \\
Human Resources & .607 & .294 & .396 & .416 \\
Effectiveness \& Product. & .508 & .099 & .437 & .063 \\
Data Resources & & & .099 \\
End User & .261 & .799 & .116 & .375 \\
Role of IS & .152 & .672 & .343 & .195 \\
Security \& Control & .446 & .669 &. .029 & .208 \\
Software Development & .194 & .635 & .842 & .141 \\
Applications Portfolio & & & .716 & .403 \\
Telecommunications & .170 & .106 & .498 & .887 \\
EDI & .355 & .286 & .091 & .622 \\
Competitive Advantage &. .045 & .141 & .179 & \\
\hline \hline
\end{tabular}

One major finding is that the high-PEU organizations make some distinction between external and internal issues; such issues load on different factors. Conversely, the low-PEU organizations do not distinguish between external and internal issues. High-PEU firms may well view issues external to the organization differently than those internal to the organization. Since the environment outside the organization is relatively unknown to these firms they may feel issues involving the environment are more difficult to address.

We also compare the factor structure of issues for our data set with that reported by Palvia and Basu (1999). Our data set supports a radically different factor structure than the earlier study. They developed an a priori model with ten factors. Our data does not support ten factors. Since the set of issues in the two studies overlap with neither being a subset of the other, a perfect comparison between the studies is not possible. However, the set of issues in our study does include a full set of variables included in their factor F1 (Data and Information Resources), factor F3 (IS Human Resouces), factor F4 (IS for Organizational Effectiveness), F5 (IS for Competitive Advantage), and F8 (IS Applications Effectiveness). To be at all consistent with their study, our study should at least support these five factors, possibly with additional variables. However, it does not. Our data set only supports the extraction of at most four factors.

In summary, our analysis shows that the perception of environmental uncertainty does affect the CIO's feelings about information systems issues that have been repeatedly rated as important in a series of past studies. Information systems issues are more important overall in high-PEU firms than in low-PEU firms. The relative importance among issues differs between high-PEU firms and low-PEU firms with at least one externally-directed issue being ranked higher in importance in high-PEU firms than in low-PEU firms. Looking beyond the individual issues to possible higher level composites of issues, a factor analysis also confirms our results with a differing factor structure for issues in high-PEU firms versus low-PEU firms. Also, externally-directed factors are more important in high-PEU firms than in low-PEU firms. 


\subsection{Suggestions for Future Research}

There are ample opportunities for follow-up studies. Since the results of Palvia and Basu's (1999) factor analysis were not supported by our data, it would be highly appropriate for another study to see if a different data set can shed light on this variation.

The results presented herein should be viewed with care. The sample includes publicly-traded United States firms limiting their operations to single industries. The results may not be representative of non-profit organizations, privately-held firms, firms headquartered in other countries, nor those which operate as conglomerates. There is ample opportunity for further studies with other populations in order to determine if our results are generalizable.

\section{References}

1. Ball, L. and R. Harris. 1982. "SMIS Members: A Membership Analysis," MIS Quarterly, Vol. 6 No. 1, pp. 19-38.

2. Brancheau, J. C., B. D. Janz, and J. C. Wetherbe. 1996. "Key Issues in Information Systems Management: 1994-95 SIM Delphi Results," MIS Quarterly, Vol. 20 No. 2, pp. 225-242.

3. Brancheau, J. C. and J. C. Wetherbe.1987. "Key Issues in Information Systems Management," MIS Quarterly, Vol. 11 No. 1, pp. 23-45.

4. Caudle, S. L., W. L. Gorr, and K. E. Newcomer. 1991. "Key Information Systems Management Issues for the Public Sector," MIS Quarterly, Vol. 15 No. 2, pp. 171-188.

5. Chenhall, R. and D. Morris.1986. "The Impact of Structure, Environment and Interdependence on the Perceived Usefulness of Management Accounting Systems," Accounting Review, Vol. 61 No. 1, pp. 16-35.

6. Choe, J., Y. Lee, and K. Park. 1998. "The Relationship Model between the Influence Factors and the Strategic Applications of Information Systems," European Journal of Information Systems, Vol. 7 No. 2, pp. 137-149.

7. Chong, V. K. 1997. "Strategic Choices, Environmental Uncertainty and SBU Performance: A Note on the Intervening Role of Management Accounting Systems," Accounting and Business Research, Vol. 27, No. 4, pp. 268-276.

8. Clark, T. D., Jr. 1992. "Corporate Systems Management: An Overview and Research Perspective," Communications of the ACM, Vol. 35 No. 2, pp. 61-75.

9. Couger, J. D. 1988. "Key Human Resource Issues in IS in the 1990s: Views of IS Executives versus Human Resource Executives," Information \& Management, Vol. 14, No. 4, pp. 161-174.

10. Dickson, G., R. Leithauser, J. C. Wetherbe, and M. Nechis. 1984. "Key Information Systems Issues for the 1980s," MIS Quarterly, Vol. 8 No. 3, pp. 135-159.

11. Duncan, R. 1972. Characteristics of Organizational Environments and Perceived Environmental Uncertainty," Administrative $\quad$ Science Quarterly, Vol. 17, pp. 313-327.

12. Dwyer, F. R., and M. A. Welsh. 1985. "Environmental Relationships of the Internal Political Economy of Marketing Channels," Journal of Marketing Research, Vol. 22, pp. 397-414.

13. Fisher, C. 1996. "The Impact of Perceived Environmental Uncertainty and Individual Differences on Management Information Requirements: A Research Note," Accounting, Organizations, and Society, Vol. 21 No. 4, pp. 361-369.

14. Gilbert, A. H., R. A. Pick, and S. G. Ward. 1999. "The Role of the CIO: Enduring MIS Issues," The Journal of Computer Information Systems, Vol. 40, No. 1, pp. 8-16.

15. Gilbert, A. H., R. A. Pick, and S. G. Ward. 2000. "Perennial Management Data Systems Issues in U.S. Manufacturing Firms," Industrial Management \& Data Systems, Vol. 100 No. 7, pp. 325-329.

16. Gilbert, A. H. and J. Singer. 1999., "The Strategic Impact of Environmental Uncertainty and Information Systems Design," Review of Accounting Information Systems, Vol. 3 No. 3, pp. 1-14.

17. Gordon, L. A. and D. Miller. 1976. "A Contingency Framework for the Design of Accounting Information Systems," Accounting, Organizations and Society, Vol. 1 No. 1, pp. 59-69.

18. Gordon, L. A. and V. K. Narayanan. 1984. "Management Accounting Systems, Perceived Environmental Uncertainty and Organization Structure: An Empirical Investigation," Accounting, Organizations and Society, Vol. 9 No. 1, pp. 33-47. 
19. Gottschalk, P. 2000. "Studies of Key Issues in IS Management Around the World," International Journal of Information Management, Vol. 20 No. 3, pp. 169-180.

20. Govindarajan, V. 1984. "Appropriateness of Accounting Data in Performance Evaluation: An Empirical Examination of Environmental Uncertainty as an Intervening Variable," Accounting, Organizations and Society, Vol 9, pp. 125-135.

21. Gul, F. A. 1991. "The Effects of Management Accounting Systems and Environmental Uncertainty on Small Business Managers' Performance,” Accounting and Business Research, Vol. 22, pp. 57-61.

22. Gul, F. A. and Y. M. Chia. 1994. "The Effects of Management Accounting Systems, Perceived Environmental Uncertainty and Decentralization on managerial Performance: A Test of 3-Way Interaction," Accounting, Organizations and Society, Vol. 19, pp. 413-426.

23. Miles, R. and C. Snow. 1978. Organizational Strategy, Structure, and Process. New York, NY: McGrawHill.

24. Miller, D. 1983. "Relating Porter's Business Strategies to Environment and Structure: Analysis and Performance Implications," Academy of Management Journal, Vol. 31, pp. 280-308.

25. Miller, D. and C. Droge. 1986. "Psychological and Traditional Determinants of Structure," Administrative Science Quarterly, Vol. 31, pp. 539-560.

26. Milliken, F. 1987. "Three Types of Perceived Uncertainty About the Environment: State, Effect, and Response Uncertainty," Academy of Management Review, Vol. 12, pp. 133-143.

27. Neiderman, F., J. C. Brancheau, and J. C. Wetherbe. 1991. "Information Systems Management Issues for the 1990s," MIS Quarterly, Vol. 15 No. 4, pp. 474-500.

28. Pagell, M., W. R. Newman, M. D. Hanna, and D. R. Krause. 2000. "Uncertainty, Flexibility, and Buffers: Three Case Studies," Production and Inventory Management Journal, Vol. 41 No. 1, pp. 35-43.

29. Palvia, P. and S. Basu. 1999. "Information Systems Management Issues: Reporting and Relevance," Decision Sciences, Vol. 30 No. 1, pp. 273-290.

30. Palvia, P., S. C. J. Palvia, and J. E. Whitworth, 2002. "Global Information Technology: A Meta Analysis of Key Issues," Information and Management, Vol 39, pp. 403-414.

31. Raymond, L., G. Paré, and F. Bergeron. 1995. "Matching Information Technology and Organizational Structure: An Empirical Study with Implications for Performance," European Journal of Information Systems, Vol. 4 No. 1, pp. 3-16.

32. Sathe, V., and D. Watson, 1987. "Contingency Theories of Organizational Structure," in K. Ferris and J. Livingstone (eds.), Management Planning and Control, Beaver Creek, OH: Century VIII, pp. 59-81.

33. Simons, R. 1987. "Accounting Control Systems and Business Strategy: An Empirical Analysis,” Accounting, Organizations and Society, Vol. 12 No. 4, pp. 357-374.

34. Wang, P. 1994. "Information Systems Management Issues in the Republic of China for the 1990s," Information \& Management, Vol. 26 No. 6, pp. 341-351.

35. Ward, S. G., A. H. Gilbert, and R. A. Pick, 2003. "Environmental Uncertainty and CIOs' Assessments of Information Systems Issues," working paper.

36. Watson, R. T. 1989. "Key Issues in Information Systems Management: An Australian Perspective," Australian Computer Journal, Vol. 21 No. 2, pp. 118-129. 